\title{
Role and Function of Wnts in the Regulation of Myogenesis: When Wnt Meets Myostatin
}

\author{
Yann Fedon, Anne Bonnieu, Stéphanie Gay, \\ Barbara Vernus, Francis Bacou and Henri Bernardi
}

Additional information is available at the end of the chapter

http://dx.doi.org/10.5772/48330

\section{Introduction}

Wnt glycolipoproteins are extracellular ligands that can be found in many species, ranging from the sea anemone to human [1]. Wnts are signaling factors regulating several key developmental processes, such as proliferation, differentiation, asymmetric division, patterning and cell fate determination [2,3]. The Wnt family consists of 19 lipid modified secreted glycoproteins that are primarily divided into two main categories based on their role in cytosolic $\beta$-catenin stabilization: canonic and non canonic $[4,5,6]$. During canonical Wnt signaling, binding of Wnt ligands to Frizzled/low-density lipoprotein-related protein (LRP) receptor complexes causes a stabilization of $\beta$-catenin, which is normally degraded by axin/glycogen synthase kinase-3 (GSK-3)/adenomatous polyposis coli (APC) complexes. Stabilized $\beta$-catenin is then able to translocate to the nucleus and through interactions with the T-cell factor (Tcf)/ lymphoid enhancer factor 1 (LEF-1), modulates the expression of specific genes [7]. These genes, by regulating cell proliferation, differentiation, adhesion, morphogenesis are involved in various essential physiological and physiopathological processes as embryonic and adult development, cellular and tissular homeostasis, and diseases $[8,9,10,11,12]$. In contrast, the less-characterized non-canonical Wnt pathways are independent of $\beta$-catenin and transduce Wnt signals through numerous signaling, including either c-Jun NH2-terminal kinases (JNK)/planar cell polarity or Wnt/calcium pathways [13,14,15,16,17].

During development, Wnts act as morphogens and control the patterning of the embryo by triggering concentration-dependent autocrine and paracrine responses $[18,19,20]$. Globally, Wnts are involved in the embryonic myogenesis by regulating the activity of myogenic regulatory factors $(\mathrm{MRF})$.

Whereas data are well established concerning the functions of Wnt proteins during embryonic muscle development, the knowledge of the implications of Wnt signaling in 
adult muscle regeneration and homeostasis is much less advanced. The ability of skeletal muscle to grow, maintain, and regenerate itself is dependent on a population of satellite cells, a specialized pool of adult myogenic stem cells, that reside in between the muscle basal lamina and the cell membrane of myofibers. Satellite cells generate muscle precursor cells that then proliferate before they either fuse into an existing myofiber to become postmitotic nuclei or fuse together to form myotubes [21,22,23]. Accumulating data show that among the signaling proteins, members of the Wnt family are strongly implicated in the adult skeletal muscle development, growth and regeneration $[24,25,26,27]$.

The role of Wnt signaling in myoblast differentiation is supported by the fact that myostatin (Mstn), a member of the transforming growth factor- $\beta$ (TGF- $\beta$ ) superfamily, negatively regulates muscle mass via non-canonical Wnt signaling pathways [28]. Mstn is an important regulator of skeletal muscle development and adult homeostasis. Naturally occurring mutations, as well as experimental knockout of the Mstn gene, lead to hypermuscular phenotype [29,30,31]. Later studies have subsequently established that Mstn regulates the size and the number of muscle fibers by inhibiting myoblast proliferation and differentiation $[32,33,34,35]$. In this context, it has been shown that, among the Wnt genes, Wnt4 was the most responsive to Mstn, both on differentiation of human bone marrow-derived mesenchymal stem cells [36] and on postnatal skeletal muscle growth [28]. Recent studies showed that Wnt4 inhibited Mstn expression and Mstn signaling pathway [37]. Reciprocally, it has been found that the genetic deletion of Mstn renders the satellite cells refractory to the hypertrophic effect of Wnt4, suggesting that the Wnt4-induced decrease of Mstn plays a functional role during hypertrophy [37]. Overall, these results indicate that Wnt factors are modulator of myogenesis and these actions can be mediated through interaction with Mstn.

In this review, we will detail Wnt signaling pathways, their implications during embryonic and adult skeletal myogenesis. A particular attention will be paid to the relation between Wnt factors, particularly Wnt4 and myostatin.

\section{Wnt signaling}

\subsection{Components of the Wnt signaling pathway}

\subsubsection{Wnts, the ligands}

Wnt proteins constitute a large family of cystein-rich secreted glycolipoproteins that control development in organisms ranging from nematode worms to mammals [38]. To date, at least 19 Wnt genes have been identified in mammals; they are similar in size, ranging from $39 \mathrm{kDa}$ to $46 \mathrm{kDa}[39,40,41]$. All Wnts have a signal sequence followed by a highly conserved distribution of cysteine residues, the spacing of which is highly conserved, suggesting that Wnt protein folding may depend on the formation of multiple intra-molecular disulfide bonds [42,43]. Once secreted, Wnt ligands remain tightly associated with the extracellular matrix, with a strong affinity for heparin sulfate proteoglycans [44,45]. In addition, Wnt ligands are carried on lipoprotein particles to facilitate signaling activities in the intercellular 
space $[46,47,48]$. Although Wnts are secreted proteins, they are highly insoluble and have therefore been difficult to be purified [39,49]. As a consequence, very little is known about the structure and biochemical properties of Wnt proteins. They mediate their signaling activity through the interaction with the seven transmembrane Frizzled (Fzd) receptor and the co-receptor LDL-receptor related protein (LRP) [50,51,52]. The Wnt family members can be divided in two distinct classes depending on their ability to induce transformation of the mouse mammary epithelial cell line C57MG [53]. The highly transforming members include Wnt1, Wnt3, Wnt3a, and Wnt7a. The intermediately transforming or non-transforming members include Wnt2, Wnt4, Wnt5a, Wnt5b, Wnt6, Wnt7b, and Wnt11 [54]. These two groups of Wnts signal via intracellular pathways that trigger different developmental outcomes [53]. In mammals, highly transforming Wnts have been associated to the canonical Wnt $/ \beta$-catenin pathway, whereas non-transforming $W n t s$ have been associated activate to the non-canonical pathway $[4,6]$. It is noteworthy that this binary classification is becoming obsolete, thus although Wnt4 was originally described as a non-canonical Wnt (nontransforming Wnt), it has also been implicated in the activation or inhibition of the canonical Wnt pathway [55,56,57,58,59,60,61]. Wnt7a has also been implicated in both canonical and non-canonical Wnt signaling depending on the cell and tissue context $[62,63]$. Non-canonical Wnt signaling pathways are less well defined, but appear to function in a $\beta$-catenin independent manner to regulate processes such as convergent extension during vertebrate gastrulation, and planar polarity $[64,65,66,67,68]$.

\subsubsection{Frizzled, the receptors}

Frizzled genes encode membrane proteins that mediate multiple signal transduction pathways. They have been identified in diverse animals, from sponges to humans. These proteins belong to the family of $\mathrm{G}$ protein-coupled receptor proteins which act as receptors for secreted Wnts $[51,69,70]$. Ten frizzled proteins have been identified in mouse and humans, and all share the following structural similarities: a signal peptide sequence at the amino terminus, a conserved region of 120 amino acids in the extracellular domain containing 10 invariantly spaced cysteines (called the cysteine rich domain CRD), a sevenpass transmembrane region, in which the transmembrane segments are well conserved, and a cytoplasmic domain with little homology among members of the family $[71,72,73,74]$. The structure of CRD domain has been solved and it appears to be necessary and sufficient for binding to Wnt [74,75]. Fzds are coupled with trimeric G proteins, and the Wnt stimulated pathway is sensitive to inactivation by pertussis toxin. Specificity of the Wnt-Fzd interaction remains largely unknown, particularly in vertebrates, because of the large numbers of Wnts and Fzds [76,77,78].

\subsubsection{LRPS, the co-receptors}

Low-density receptor-related protein 5 and 6 (LRP-5 and LRP-6), which are highly homologous, are members of the low-density-lipoprotein (LDL) family of receptors $[79,80]$. LRP functions as a co-receptor for Wnt signaling leading to the activation of the $\mathrm{Wnt} / \beta$ catenin pathway. LRP-5 and LRP-6 are type I single-span transmembrane proteins 
$[81,82,83]$. LRP-5 and -6 , which bind to Axin through their intracellular domain, are key signaling receptors for the $\beta$-catenin pathway $[84,85]$. The binding between LRP5 and LRP6 is directly associated to the stabilization of $\beta$-catenin [79].

\subsubsection{Secreted modulators of the Wnt pathway}

The extracellular antagonists of the Wnt signaling pathway can be divided into two broad classes. The first class, which includes the secreted Frizzled receptor (sFRP), primarily binds to Wnt proteins; the second class comprises the Dickkopf (Dkk) family, which binds to the LRP subunit of the Wnt receptor complex $[86,87,88]$. Both classes of molecules prevent ligand-receptor interactions by different mechanisms [89]. sFRPs share homology in the Nterminal region with the cysteine-rich domain of Frizzled proteins, but lack the transmembrane domain [90,91]. sFRPs inhibit Wnt signaling by competing with Fzd for Wnt ligands or in a dominant negative fashion by forming a non-signaling complex with Wnt [92]. There are presently five known members of the family in mouse, sFRP1 to sFRP5. sFRPs are composed of a cysteine rich domain (CRD) and a domain that shares weak sequence similarity with the axon guidance protein netrin (NTR) in the C-terminus $[93,94]$. The CRD shares 30-50\% sequence similarity with those of Fzd proteins and includes 10 conserved cysteine residues.

The four members of the Dickkopf (Dkk) family (Dkk-1 to Dkk-4), inhibit Wnt signaling by binding to the LRP-5 and LRP-6 components of the receptor complex [87,95]. Dkks contain two characteristic cysteine-rich domains (Cys-1 and Cys-2) separated by a linker region of variable length. Cys-2, in particular, is highly conserved among all 69 members of the family and contains 10 conserved cysteine residues [88,89].

\subsubsection{Dishevelled}

Dishevelled $(D v l)$ is a phosphoprotein essential for the transduction of the Wnt signaling pathway. The Dvl family comprises three Dvl proteins (Dvl-1, Dvl-2, and Dvl-3). The structure of $D v l$ family members consist of three highly conserved domains: an aminoterminal DIX domain, a central PDZ domain, and a carboxy DEP domain [96]. Dvl act as a key transducer of the Wnt signal and act at the plasma membrane or in the cytoplasm. $D v l$ is differentially targeted to participate in either $W n t / \beta$-catenin or PCP signaling $[6,7,97]$. Activation of a specific pathway through $D v l$ depends on its subcellular localization and activation of modulator downstream. In Wnt/ $\beta$-catenin pathway, once Wnt binds to the Fzd transmembrane receptor and the co-receptor LRP5/6, Dvl can interact with the Fzd/LRP complex. $D v l$ is phosphorylated by casein kinase I $\varepsilon$ to form a complex with Frat1 and inhibits GSK3 $\beta$ activity, leading to stabilization of cytoplasmic $\beta$-catenin.

The Planar cell polarity pathway makes use of $D v l$ to modify the actin cytoskeleton $[98,99]$. At the level of $D v l$, an independent and parallel pathway leads to the activation of the small GTPases Rho [66]. Rho signaling occurs through the molecule Dishevelled associated activator of morphogenesis 1 (DAAM1) [66]. The Rho pathway leads to the activation of Rho associated kinase, which mediates cytoskeletal reorganization $[6,99]$. 


\subsection{The canonical or $W n t / \beta$-catenin pathway}

Wnt family glycoproteins are primarily divided into two main categories based on their role in cytosolic $\beta$-catenin stabilization: canonic and non-canonical $[4,5,6,100]$ (Figure 1). Signaling through the Wnt/ $\beta$-catenin pathway also called canonical pathway, modify the stabilization of $\beta$-catenin. In the absence of Wnt binding to Frizzled receptors, $\beta$-catenin is targeted for degradation by a multi-protein destruction complex composed of the tumor suppressor protein APC (adenomatous polyposis coli gene product), axin, and glycogen synthase kinase $3 \beta$ (GSK3 $\beta$ ) [101,102]. This process is triggered by phosphorylation of $\beta$-catenin by the serine/threonine kinases, GSK3 $\beta$ and Casein Kinase [103]. In the complex, the interaction between these kinases and $\beta$-catenin is made easier by the scaffolding proteins Axin and APC $[104,105,106,107]$. Phosphorylated $\beta$-catenin is recognized by $\beta$-transducin repeat containing protein $(\beta-\operatorname{TrCP})$, targeted for ubiquitination, and degraded by the $26 \mathrm{~S}$ proteasome $[108,109]$. Binding of Wnts to its receptors Frizzled and its co-receptor LRP5/6, inhibits the kinase activity of the destruction complex, and leads to the stabilization of non-phosphorylated $\beta$ catenin [110,111]. This mechanism involves either the recruitment of Axin to the plasma membrane after the phosphorylation of LRP5/6, or the action of an axin-binding molecule, Dishevelled $(D v l)[96,112]$. Kinase inhibition leads to the accumulation of free cytosolic $\beta$ catenin. The elevated cytosolic $\beta$-catenin can translocate to the nucleus, where it interacts with the $\mathrm{N}$-terminus of the DNA-binding proteins of the T-cell factor/Lymphoid enhanced factor (Tcf/Lef) family $[113,114,115]$. This transient interaction with $\beta$-catenin converts Tcf/Lef factors into transcriptional activators. In the absence of Wnt, Tcf/Lef proteins repress target genes through a direct association with co-repressors such as Groucho $[102,116,117]$.

\subsection{Non-canonical signaling pathways}

In contrast, non-canonical Wnts transduce their signal independently of $\beta$-catenin. The noncanonical Wnt signaling pathway has been found to be associated with gastrulation movements, heart induction, dorsoventral patterning, tissue separation and neuronal migration [6]. Unlike the canonical Wnt signaling pathway, the non-canonical Wnt signaling pathway is quite diverse. Thus, it has been reported that non-canonical Wnts can activate calcium flux, G proteins, Rho GTPases, or c-Jun N-terminal kinase (JNK) $[6,66,82]$.

The response to a given stimulus depends not only on which Wnt is present, but also on which cognate receptor is expressed on the cell [118], It is likely that one Wnt protein can signal more than one type of response in a cell if multiple types of receptors are present [58]. Adding still more layers of complexity, cofactors, secreted antagonists and co-receptors of Wnt signalling are likely to affect both canonical and non-canonical actions $[89,119]$.

\subsubsection{Calcium pathway}

Activation of this signaling pathway involves Wnt binding to a Frizzled receptor, subsequent release of intracellular calcium associated with the activation of various enzymes such as $\mathrm{Ca}^{+} /$calmodulin-dependent (CamKII) protein kinase and Protein Kinase C (PKC) [6,120,121,122] (Figure 1). Here, frizzled receptors act through G-protein and activate phospholipase C (PLC) 


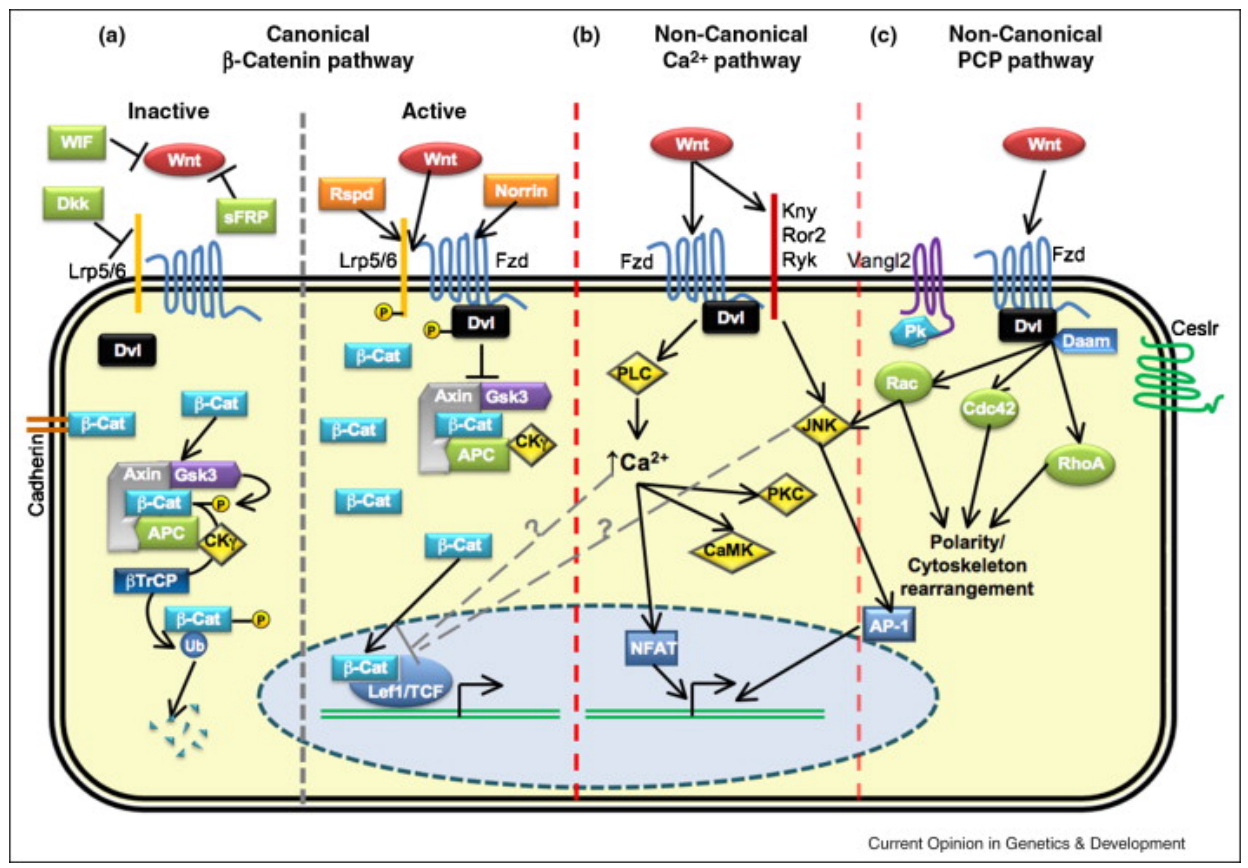

From Franco et al. Current Opinion in Genetics \& Development 2009, 19:476-483

Figure 1. Three Wnt-dependent pathways have been proposed: (a) canonical Wnt/ $\beta$-catenin pathway and (b and c) non-canonical Wnt/PCP and Wnt/Ca2+ pathways. Canonical and non-canonical pathways possess clear different signaling events; however, the distinction between Wnt/PCP and Wnt/Ca2+ pathways is less obvious and common events occur on those pathways. (Dashed lines illustrate the idea that no clear boundaries exist between the different Wnt pathways.) (a) Canonical Wnt/ $\beta$-catenin pathway. In cells, $\beta$-catenin is normally associated with adherens junctions and can also be free in cytoplasm. In cells non-stimulated by Wnt ligands (which can additionally be inhibited by WIF, sFRPs and Dkk protein family members) cytosolic $\beta$-catenin is targeted to proteolytic degradation through phosphorylation by the APC-Axin-GSK3 $\beta-\mathrm{CK} 1 \gamma$ complex and further ubiquitination through action of $\beta$ TrCP-dependent E3 ubiquitin ligase complex. On stimulation by Wnt ligands though binding to Fzd receptors and its co-receptors Lrp5/6, Fzd recruits Dvl. Dvl will inhibit APC-Axin-GSK3 $\beta-C K 1 \gamma$ complex formation by the recruitment and inhibition of GSK3 $\beta$, CK1 $\gamma$ and Axin to the cytoplasmic membrane. Consequently, $\beta$-catenin can accumulate in the cytoplasm and enter the nucleus, activating transcription of target genes through association with Lef1/TCF transcription factor family. (b) Noncanonical Wnt/Ca2+ pathway. Interaction of Wnt ligands with Fzd receptors can lead to an increase in intracellular calcium level, through possibly the activation of PLC. Intracellular calcium will subsequently activate CAMKII and PKC in cells, as well as the transcription factor NFAT. This pathway is particularly important for convergent-extension movements during gastrulation. Additionally, Fzd receptors in association with Kny, Ror2 or Ryk receptors can also activate JNK promoting expression of specific genes through activation of AP-1. (c) Non-canonical Wnt/PCP pathway. This pathway is characterized by an asymmetric distribution of Fzd, CELSR, Pk and VANGL2, resulting in the polarization of the cell. Also, Wnt-signaling activates Rho GTPases Cdc42, RhoA and Rac1 leading to cytoskeleton rearrangement, with the participation of Daam1. Rac1 can also activate JNK, activationspecific gene transcription through modulation of AP-1 protein complex. 
and phosphodiesterase (PDE), which lead to increased concentrations of free intracellular calcium and to decreased cyclic guanosine monophosphate (cGMP) [121,123,124]. Elevated free intracellular calcium can activate the phosphatases calcineurin, leading to dephosphorylation and activation of the transcription factor NFAT [14].

\subsubsection{Planar cell polarity pathway}

The planar cell polarity $(\mathrm{PCP})$ pathway regulates the orientation and migration of polarized cells during development and defects underlie severe abnormalities $[66,67,125]$. Although, the regulation of this pathway appears to be incredibly complex, in vertebrates, it signals mainly through the JNK pathway. Upon binding of Wnt to its receptor Frizzled, there is activation of Disheveled, JNK and Rho family GTPases, which direct asymmetric cytoskeletal organization and coordinated polarization of cells within the plane of epithelial sheets [68,126,127] (Figure 1).

\section{Implication of Wnt signaling in skeletal myogenesis}

\subsection{Embryonic skeletal myogenesis}

Like any process of tissue development, skeletal muscle development is under the control of two regulation pathways: an intrinsic pathway implicating transcription factors (Pax3, Pax7, Myf5, MyoD1, Mrf4, Myogenin, Six proteins, SRF....) and an extrinsic pathway implicating external factors as Wnt, sFRP, Myostatin, Sonic Hedgehog (Shh), BMP, Notch, FGF, HGF/Met, insulin, IGF1, retinoic acid....

\subsubsection{Intrinsic pathway}

Muscles of the trunk and limbs of vertebrate embryos are derived from somites. These segmental masses correspond to a series of transient repeated epithelial structures that derive from the paraxial mesoderm and lie on either side of the neural tube [128]. Somites eventually differentiate into five major cell types: cartilage, bone, and tendons of the trunk, skeletal muscles of the body and the dermis of the back [128,129,130,131]. This process is regulated by sonic hedgehog $(S h h)$ and Wnt signals that are secreted by tissues surrounding the somites [132,133]. This process leads to patterning of the epithelial structures into distinct compartments that give rise to diverse cell lineages $[129,131,133,134]$. The compartments formed are (i) the mesenchymal sclerotome which contributes to cartilage and bone of the vertebral column and ribs and (ii) the dorsally located epithelial dermomyotome where myogenic precursors are localized and ultimately give rise to epaxial (back) and hypaxial (muscles of the ventral body wall, limbs, diaphragm and tongue) muscles $[134,135]$. All cells of the dermomyotome, including the epaxial and hypaxial zones, are initially positive for the Pax3 transcription factor, whereas Pax3/Pax7 double positive cells are only located in the central domain [136]. Myogenesis is initiated by the translocation of myogenic progenitors that migrate as Pax3 positive cells from the extremities of the dermomyotome to the myotomal layer below or as Pax3/7 double positive 
cells from the central dermomyotome to the myotome $[128,133,137,138,139,140,141]$. These cells enter the myogenic program after activating of the myogenic regulatory factors (MRFs): Myf5 and Mrf4 [2,142]. Double mutant Pax3/Pax7 mouse embryos suffer from a major skeletal muscle deficit where only the early myotome is formed, but the cells in these structures do not activate Myf5 or MyoD and consequently fail to enter the myogenic program consequently, they die or migrate towards a non myogenic fate $[143,144]$. Pax3 and Myf5/Mrf4 control the activation of MyoD, another MRF family member and MyoD positive myogenic precursors differentiate into myofibers or remain as a proliferating population called satellite cell population $[145,146]$.

\subsubsection{Extrinsic pathway}

Numerous environmental paracrine factors are associated to the regulation of skeletal myogenesis, thus, for example, Notch signaling plays a role in cell fate determination in the lateral dermomyotome [147], in the amplification of Pax3+/Pax7+ progenitors cells and in the myoblastic proliferation [148].

Overall, Wnt protein family has been determined along with Shh to be the main molecules required to activate myogenesis [149,150,151,152] (Figure 2).

In response to Shh and Wnt signals from the notochord and neural tube, somites delaminate to form the sclerotome and dermomyotome. The notochord and the floor plate of the neural tube secrete ventralizing signals, including Shh whereas the surface ectoderm and the dorsal neural tube secrete Wnt proteins [153]. These two morphogens will induce the induction of MRFs leading to the delamination, specification and myoblast differentiation.

In a remarkable study realized from chicken cultures of presomitic mesoderm cells, A.E Munsterber et al. have shown that Wnts could mimic the inducer effect of the dorsal neural tube and that Shh could mimic the effect of the floor plate and the notochord $[25,154]$. These results indicated that Wnt1, Wnt3, Wnt4 and Shh could replace the inducer role of the dorsal neural tube and the floor plate/Notochord structures. Ectopically implanted Wnt1, Wnt3a and Wnt4 expressing cells in chicken alter the process of somite compartmentalization in vivo, resulting in an enhanced recruitment of somitic cells into the myogenic lineage [155]. In the same study, authors reported no difference on somite development between neural tube (expressing Wnt1 and 3a) and surface ectoderm (expressing Wnt4), suggesting that surface ectoderm promote myogenesis by Wnt4 secretion [155].

In mouse, similar experiments indicated that the expression of Myf5 is induced by a signal emanating from neural tube and that the expression of MyoD is depending of a signal coming from surface ectoderm [156]. Wnt7a secreted by the surface ectoderm and Wnt1/Wnt3a secreted by dorsal neural tube regulate MyoD and Myf5 expression, respectively whereas Wnt4 and Wnt5a regulate both MyoD and Myf5 expression [132]. Furthermore, it has been shown that Wnt1, Wnt3a and Wnt4 are expressed in the dorsal half of the neural tube when epaxial myogenesis is initiated [153]. Regulation of hypaxial muscle specification is less understood but Tajbakhsh et al, 1998 have shown that Wnt7a and to a 
lesser extent Wnt4 and Wnt5a can activate myogenesis in mouse paraxial mesoderm explants [132]. Conversely, sFRPs, inhibitor of Wnt signaling, markedly reduce myogenesis by antagonizing Wnts $[157,158]$.

Use of somites from transgenic mice expressing lacZ reporter gene under the control of Myf5 epaxial promoter in presence of a constitutive form of $\beta$-catenin or in presence of the neural tube lead to a strong activation of the reporter, indicating that the Wnts secreted by the neural tube act mainly through canonical pathway [159]. In the surface ectoderm, signaling pathway initiated by Wnt7a differs from that by Wnt1. Wnt7a binds to Frz7 and signals through Protein kinase C, a $\beta$-catenin independent pathway $[122,149]$. Recently, the Wnt PCP pathway has been implicated in regulating the orientation of myocyte growth in the developing myotome [160]. As reported during osteogenic differentiation or during recruitment, maintenance, and differentiation of human bone marrow mesenchymal stem cells a cross-talk between canonical and non-canonical Wnt signaling exists and may lead to functional antagonism [161,162].

In chick embryos, Nohno's group analyzed the myogenic effects of Wnt4 overexpression in the limb bud in order to evaluate the significance of this factor in skeletal muscle formation during embryogenesis. They found that Wnt4 treatment induced an increase in the muscle mass, particularly in fast-type muscle size. Furthermore, ectopic Wnt4 induces muscle satellite markers Pax7 and MyoD expression [60].

As extrinsic factors, myostatin (Mstn), a member of the TGF- $\beta$ superfamily, has been proposed as a regulator of embryonic myogenesis [30,32,34,163,164,165,166]. Myostatin, also called GDF8 (growth differentiation factor 8), is a secreted growth factor that belongs to the transforming growth factor- $\beta$ (TGF- $\beta$ ) superfamily of growth and differentiation factors [30]. In mice, myostatin is predominantly expressed in skeletal muscle tissues from the period of embryogenesis to adulthood suggesting a role for this factor in the control of muscle development and function $[30,166]$. The role of myostatin in muscle comes from the phenotype of myostatin-deficient animals. Myostatin was first found to regulate muscle mass in mice from which the gene encoding myostatin has been knocked-out. The resulting "mighty mice" displayed muscle overgrowth due to both hyperplasia (increased number of muscle fibers) and hypertrophy (increased size of individual muscle fibers). These effects on muscle mass are persistent throughout the life of the animals. The phenotype of these mice suggested that myostatin functions as a negative regulator of muscle growth. Interestingly, the function of myostatin appears to have been conserved across diverse species. Natural mutations in the myostatin gene have been identified in double-muscled animals such as the Belgian blue cattle $[29,167,168]$. The recent identification of a hypermuscular child with a loss-of-function mutation in the myostatin gene suggests that the function of myostatin is similarly conserved in humans [169]. In support of this, myostatin sequence has been highly conserved through evolution, among species ranging from zebrafish to humans [30]. At early embryonic stages, myostatin expression is restricted to the myotome compartment of the developing somites, and myostatin has been proposed to play an essential role in skeletal muscle growth and development $[30,165]$. 
It is of note that many others autocrine or paracrine factors, such as Notch, Tgf- $\beta 1$, Bmp, Noggin, mi-RNA..., play a subtle but crucial role in orchestrating the regulation of embryonic myogenesis $[170,171,172,173,174,175,176]$. Undoubtedly, the complete decoding of this intricate network will take several years to be complete.

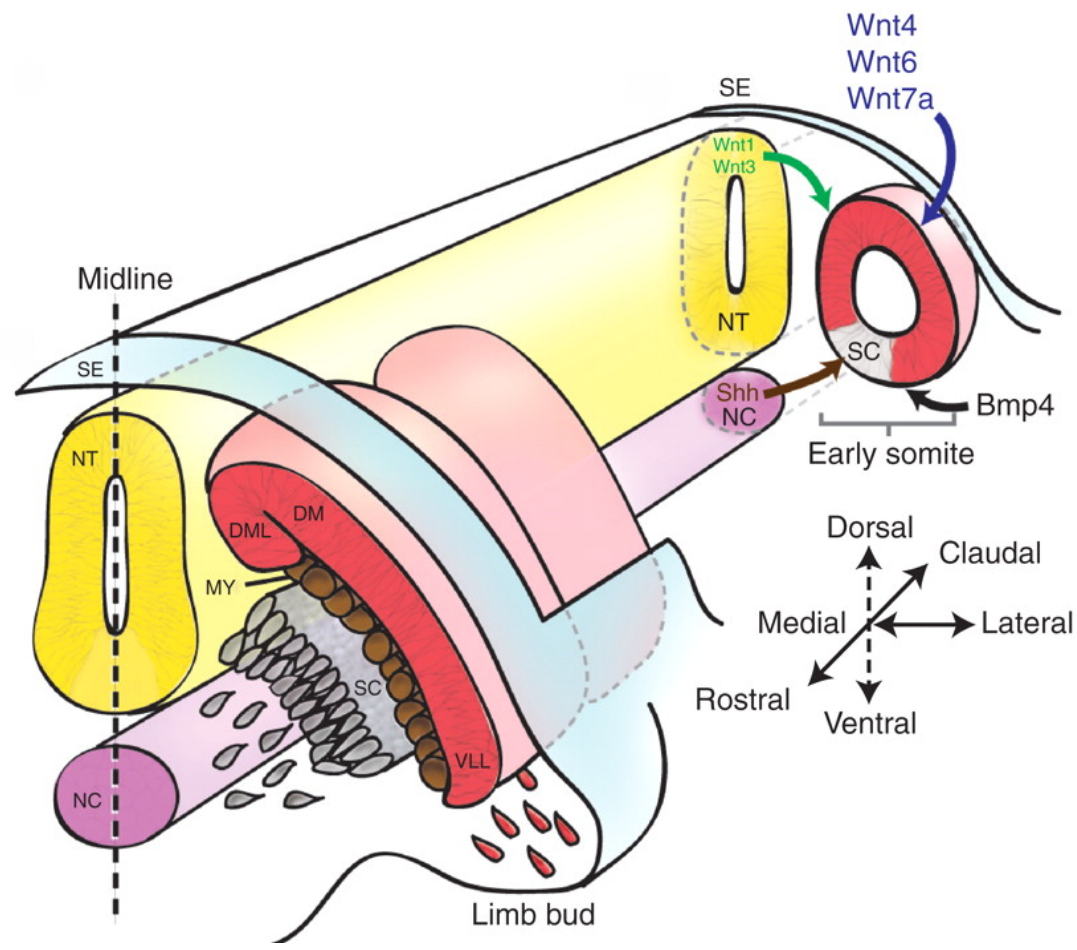

From Bentzinger et al. Cold Spring Harb Perspect Biol 2012

Figure 2. Embryonic myogenesis. Illustration of the morphogen gradients along the rostral-caudal axis of the embryo. (C) Schematic of transverse sections through the embryo at early (i) and late (ii) stages of somitogenesis. (Ci) Morphogens secreted from various domains in the embryo specify the early somite to form the sclerotome (SC) and dermomyotome (DM). Wnts secreted from the dorsal neural tube (NT) and surface ectoderm (SE) along with bone morphogenetic protein (BMP) from the lateral plate mesoderm maintain the undifferentiated state of the somite, whereas Sonic hedgehog (Shh) signals from the neural tube floor plate and notochord (NC) induce the formation of the sclerotome. (Cii) As the sclerotome segregates, muscle progenitor cells (MPCs) from the dorsomedial (DML) and ventrolateral (VLL) lips of the dermomyotome mature give rise to the myotome (MY). At the level of the limb bud, Pax3-dependent migrating MPCs delaminate from the ventrolateral lips to later give rise to limb muscles.

\subsection{Postnatal myogenesis}

\subsubsection{Satellite cells}

The main role of satellite cells during the early postnatal period is to provide myonuclei for skeletal muscle growth. They contribute to the postnatal growth of syncital muscle cells, 
which in adults contain approximately 6-8 times more nuclei than in neonates [177]. In adult muscle, satellite cells are mitotically quiescent and do not express myogenic regulatory factors (MRFs) [178,179]. Their role changes to one of providing myonuclei for homeostasis and hypertrophy or in response to the more sporadic demands for myofiber repair and regeneration [180]. In the latter context, satellite cell activation is dramatically enhanced; they reenter the cell cycle and proliferate [181,182], at this stage they are often referred to as either myogenic precursor cells or myoblasts [182,183]. Some resulting myoblasts differentiate and fuse to form replacement myofibers, whereas some remain as continual dividing cells to replenish the pool of satellite cells in anticipation of future rounds of regeneration $[182,184]$.

Pax7 is expressed in quiescent as well as activated satellite cells, and it is down regulated when satellite cells commit to muscle differentiation [177,185,186]. Compared to embryonic satellite cells, quiescent adult satellite cells do not require Pax7 for self-renewal and regeneration [187]. The progression of activated satellite cells toward myogenic differentiation is mainly controlled by Myf5 and MyoD [188] and is followed by fusion into regenerating fibers. Satellite cells undergo different fates, giving rise to a few Pax $7+\mathrm{MyoD}$ cells, which return to quiescence (satellite stem cell population), and many Pax7+MyoD+ cells, which differentiate [189]. These asymmetric divisions are mainly regulated by Notch signaling [190,191,192]. In addition, satellite stem cells which represent approximately $10 \%$ of Pax7+ mouse satellite can undergo planar symmetric cell divisions to drive expansion of their population [190]. By a subtractive hybridization approach, Legrand et al. found that Wnt7a is expressed during muscle regeneration and acts through Fzd7 receptor to induce symmetric satellite stem cell expansion and thus enhance muscle regeneration. Wnt7a signaling though Frz7 receptor requires association with Vang12, a membrane protein involved in the regulation of PCP suggesting that Wnt7a utilizes this non-canonical pathway to control the orientation of satellite cell division [62]. They suggest that Wnt7a regulates the homeostatic maintenance of the satellite stem cell pool by modulating the increase in satellite stem cell expansion during regenerative myogenesis and that basal levels of PCP signaling are insufficient to maintain the satellite cell pool at normal levels [62].

Aging is accompanied by a decline in muscle mass and strength, a phenomenon referred as to sarcopenia [193]. It is clear that fitness is greater at any age in individuals who exercise regularly versus those who do not and that sarcopenia is reduced in physically active elderly people. A decline in the number of satellite cells, their proliferative capacities, or both, may contribute to sarcopenia. One of the mechanisms responsible for the reduced regenerative potential of old muscle seems to be the decline in Notch signaling [194]. Aging of skeletal muscle is characterized by an increase in fibrous connective tissue and adipose tissue and by an impairment of muscle regenerative potential [195,196]. This decrease of aged-muscle regeneration can be enhanced by direct activation of the Notch pathway [194] or by exposure to a youthful systemic environment [197]. Very interestingly, these agerelated effects are associated with increased canonical Wnt signaling in the satellite cell population, possibly resulting from increased amounts of Wnt or Wnt-like molecules in the serum of aged animals [24]. This generalized role of Wnt signaling in promoting an aging phenotype is consistent with the findings of Liu et al. [198]. 


\subsubsection{Non satellite cells}

Interestingly, a variety of non-satellite cell, located outside the basal lamina can also participate in skeletal muscle regeneration in the adult. These include pericytes, endothelial cells, mesoangioblasts [177,199,200,201,202], and interstitial cells (PICs) [203], as well as other cell types that are not fully characterized [26,204,205]. Polesskaya et al. found that a side population of cells harboring surface markers CD45 and Sca1 (CD45+:Sca1+) isolated from regenerating muscle readily underwent myogenic differentiation in vitro [26]. As quiescent satellite cells, activated satellite cells and satellite cell derived myoblasts do not express CD45 and satellite cell lineage do not express Sca1, CD45+:Sca1+ cells constitute a cellular pool distinct of muscle satellite cells. The fact that (i) activation of the canonical Wnt pathway by $\mathrm{LiCl}$ in isolated CD45+:Sca1+ cells was sufficient to induce muscle specification, (ii) myogenic commitment of CD45+:Sca1+ cells were induced by co-culture with cells ectopically expressing Wnt proteins and, (iii) the number of CD45+:Sca1+ cells was decreased in injured muscle treated with sFRPs, demonstrated clearly a functional requirement for canonical Wnt in the myogenic specification of CD45+:Sca1+ cells. These exciting results establish that myogenic progenitors derived from non-satellite cell can have a physiological role in muscle regeneration.

\subsubsection{Wht-related regulation of myoblast proliferation and differentiation}

In addition to the crucial role of Wnt proteins in satellite cells fate and maintenance, they play an essential role in the control of proliferation and differentiation in various cellular types.

In order to better characterize the role of Wnt proteins in the control of muscle cell differentiation, Bernardi et al. established Wnt expression pattern on C2C12 myoblasts and satellite cells [37]. They found that, among the 19 existing Wnts, only the expression of Wnt4 was strongly activated from the early steps of differentiation. Interestingly, by modulating Wnt4 expression level with overexpression or silencing approaches, they reported a strong differentiation promoting activity of this factor (Figure 3). The relative increase in myotube size being comparable 48,72 , and $96 \mathrm{~h}$ after switching to differentiation medium indicates that Wnt4 signaling controls myotube size at the early steps of differentiation during myotube formation. The lack of Wnt4-mediated hypertrophic effect observed when cells were transfected the day of differentiation or later indicates that this factor has to be expressed during the proliferative stage to be effective.

Fusion consists of two distinct phases: myoblast/myoblast fusion to form nascent myotubes and subsequent myoblast/myotubes fusion, resulting in a rapid accretion of size. The efficiency of the first phase can be evaluated by measuring the fusion index, which represents the proportion of the total cell population that has fused. After being switched to differentiation medium, Wnt4 overexpression in C2C12 and satellite cells gave a $62 \%$ and a $67 \%$ fusion index increase, respectively, suggesting that Wnt 4 signaling control nascent myotube formation. Recently, Tanaka et al. confirms that Wnt4 overexpression increased troponin- $\mathrm{T}$ positive cells in proliferation medium and enhanced myotube formation of differentiated C2C12 cells [206]. 
Takata et al. reported that Wnt4 exhibited a low but significant myogenic activity with an increase of proliferation rate in myoblast cells [60]. Conversely, Otto and co-workers found, using co-culture of Wnt4-producing NIH-3T3 cell line on single muscle fiber culture, a $24 \%$ reduction of satellite-cell proliferation [207]. These conflicting results could be attributed either to the different specificities of the cellular models used or to the fact that effective concentration and physiological activity of ectopicWnt4 can be eminently variable, depending on the nature and activity of produced Wnt4. Taken together, these data are in agreement with a modest effect of Wnt4 on proliferation, suggesting a role of this factor in enhancing cell fusion rather than controlling the number of nuclei available for fusion.

Knockdown of Wnt4 expression in C2C12 and satellite cells inhibits their differentiation and further confirms that Wnt4 acts as an effector of myogenesis (Figure 3). However, addition of siWnt 4 after switching to differentiation medium or $24 \mathrm{~h}$ before did not decrease significantly the differentiation rate. This confirms that Wnt 4 acts as a positive regulator of myogenic differentiation only if it is expressed in the proliferative phase.
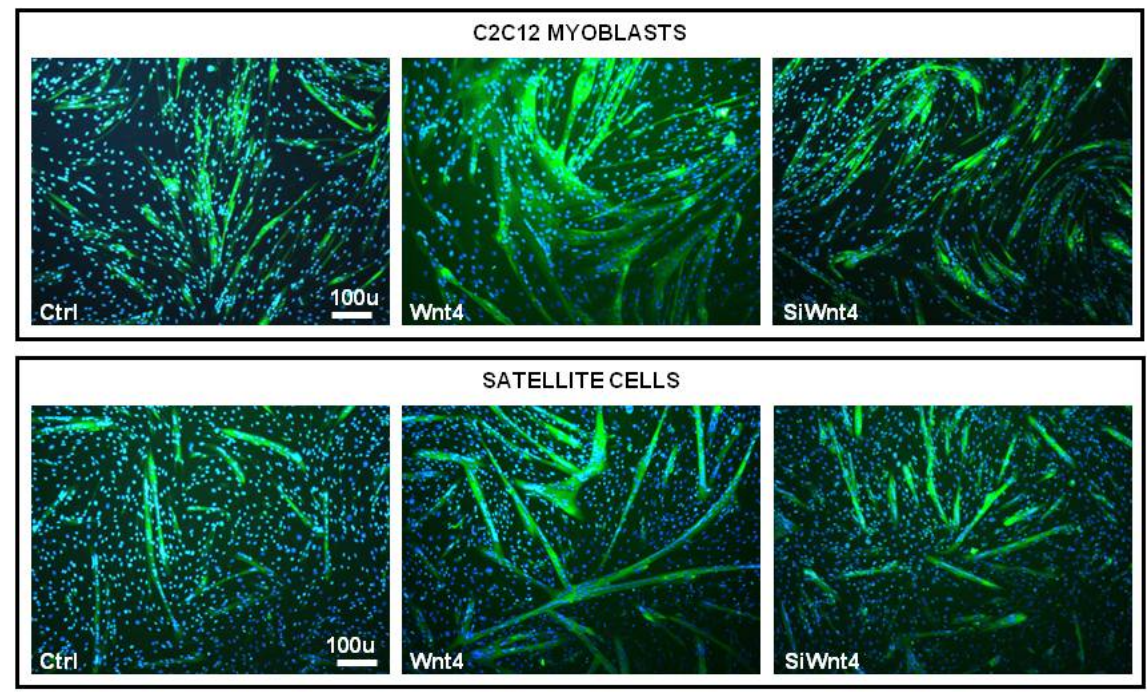

From Bernardi et al. Am J Physiol Cell Physiol-2011

Figure 3. Effects of Wnt4 overexpression and Wnt4 silencing on $\mathrm{C} 2 \mathrm{C} 12$ myoblasts and satellite cells differentiation. Stably transfected polyclonal C2C12 myoblasts with empty (Ctrl) or Wnt4-containing (Wnt4) expression vector were grown 2 days in proliferation medium followed by 4 days in differentiation medium. C2C12 myoblasts and satellite cells transfected with siRNA specific to Wnt4 (siWnt4) and negative control siLuc were grown 2 days in proliferation medium followed by 4 days in differentiation medium. Fluorescent images of $\mathrm{C} 2 \mathrm{C} 12$ myoblasts were obtained by immunostaining with a monoclonal anti-myosin antibody. Nuclei were labeled by DAPI staining.

Myoblastic differentiation involves two major steps, their reversible withdrawal from cell cycle and the subsequent expression and activation of myogenic factors. Myf5 and MyoD are expressed in early myogenesis. As cells progress toward a differentiated phenotype, 
myogenin and MRF4 are induced and cooperatively establish the irreversible commitment to terminal differentiation. Myf5 is a factor reported to be high in the Go phase, where cells were arrested to differentiate [208]. Borello et al. have previously showed a direct regulation of Myf5 expression by canonical Wnt signaling during somitogenesis [2]. Bernardi et al. found that the expression of Myf5 was activated by Wnt4 overexpression and strongly inhibited by Wnt4 silencing during $\mathrm{C} 2 \mathrm{C} 12$ myoblast and satellite cells differentiation, suggesting that myogenic activity of Wnt4 is related to an increase of Myf5 expression.

These authors by measuring Tcf/LEF gene canonical reporter activity and axin2 expression (a protein induced by canonical Wnt pathway), in the presence or absence of canonical Wnt pathway stimulators ( $\mathrm{LiCl}$ or $\mathrm{BIO}$ ), reported canonical Wnt pathway activation by Wnt4. Although this factor was originally described as a non-canonical Wnt, it has also been implicated in the activation or inhibition of the canonical Wnt pathway $[55,56,57,58,59,60,61]$. Numerous reports showed that Wnt-related myogenic activity is mediated mainly through a stimulation of canonical signaling. Thus, Takata et al. found that myogenic activity of Wnt4 is linked to an increase of $\beta$-catenin signaling [60]. Likewise, Armstrong et al. have reported that the expression of $\beta$-catenin is necessary for physiological growth of skeletal muscle and that Wnt signaling pathway induces $\beta$-catenin activation of growth-control genes during overload induced skeletal muscle hypertrophy $[209,210]$. By using C2C12 and satellite cells, Han et al. reported recently that activation of canonical pathway by R-spondin2, promote myogenic differentiation and hypertrophic myofiber formation [211]. When $\mathrm{LiCl}$ was added to the culture medium, the area of myotubes and index fusion were increased in both $\mathrm{C} 2 \mathrm{C} 12$ and satellite cells, reaching values similar to those observed after Wnt4-induced hypertrophy [37]. On the other hand, the fact that $\mathrm{LiCl}$ exerts a higher Tcf/LEF activation than Wnt4 treatment, whereas the extent of differentiation is the same suggests that this process is dependent on other signaling pathways. In this respect, work of Otto et al. (61) on isolated muscle fibers showed that Wnt4 inhibited satellite cell proliferation but that canonical Wnts such as Wnt1, Wnt3a, and Wnt5a induced a greater degree of proliferation than control cells, confirming the implication of other pathways in Wnt4 signaling [207]. The stronger activity in terms of Tcf/LEF activation of $\mathrm{LiCl}$ compared with Wnt $4(+100 \%$ on C2C12 myoblasts, $+250 \%$ on satellite cells) treatments could explain the discrepancy between proliferative activities of Wnt4 and LiCl. Indeed, as described above, Wnt4 shows a weak effect on mitogenicity, whereas $10 \mathrm{mM} \mathrm{LiCl}$ has a strong anti-proliferative activity $(-15 \%$ on satellite cells, $-48 \%$ on satellite cells), suggesting that low levels of Tcf/LEF activation regulate myogenic differentiation, whereas higher levels regulate preferentially the proliferation. A study reported by Anakwe et al. is also in agreement with a relation between the level of Tcf/LEF activity and the type of cellular response elicited [209]. They reported an increase in the number of terminally differentiated cells in Wnt 4 transfected myogenic cells, whereas the overexpression of canonical Wnt3a decreases the number of terminally differentiated myogenic cells. Making more complex the Wnt4-related signaling in muscle, Tanaka et al. showed very recently that Wnt4 promotes myogenesis and suppresses canonical Wnt signaling, culture conditions and $\mathrm{C} 2 \mathrm{C} 12$ myoblasts characteristics may be at the origin of 
this discrepancy and suggest that data emanating from established cell lines should be considered with care [206]. Moreover, the analysis of cellular response during myoblast differentiation can be made more complex by the implication of other signaling pathways like the non-canonical Wnt/calcium signaling.

Recently, an elegant work from Rudnicki's group showed that Wnt signaling is also implicated in the control of muscular hypertrophy [27]. Skeletal muscle mass depends upon a dynamic balance between anabolic and catabolic processes. Muscle hypertrophy is characterized by an increase of the diameter of muscle fibers and increased protein synthesis, mainly by activation of the IGF1/Akt/mTORC1 pathway. They observed that Wnt7a binding to Fzd7 receptor directly activates the Akt/mTOR growth pathway, thereby inducing myofiber hypertrophy. Besides, they found that anabolic activity of Wnt7a is related to the activation of a new non-canonical pathway implicating stimulatory $\mathrm{G}$ protein, $\mathrm{G} \alpha \mathrm{s}$.

\subsubsection{Relation between Wnt4 and Myostatin}

Myostatin acts through the receptor-associated proteins Smad2 and Smad3 [33,212,213]. Phosphorylated Smad2 and Smad3 form heterodimeric complex with the common mediator Smad4. These activated Smad proteins function as the key intracellular mediators of signaling for myostatin as they translocate into the nucleus, and activate the transcription of the target genes through interaction with DNA and other nuclear factors [214,215]. Takata et al. reported that Wnt4 had no effect on Smad2 phosphorylation, but it antagonized Smad2 phosphorylation induced by Mstn in differentiated C2C12 myoblasts [60]. They suggest that Wnt4 exert its myogenic effect by acting against Mstn. By using CAGA reporter assay, Bernardi et al. confirmed the inhibition of Mstn-activated Smad signaling pathway by Wnt4 [37]. Contrary to differentiated myoblasts, Wnt4 decreased the CAGA reporter activity in proliferating myoblasts below the basal level meaning that Wnt4 has a stronger anti-Mstn activity during proliferation than during differentiation. Furthermore, the fact that the addition of Mstn did not reverse the Wnt4-induced CAGA reporter inhibition in myoblasts and satellite cells suggests that Mstn acts upstream of Wnt4 or that Wnt4 regulates the Mstn/Smad pathway independently of Mstn. The inhibition of the Mstn pathway by Wnt4 can be associated with the inhibition of Mstn expression and/or inhibition of the Mstn/Smad transduction pathway. By using sqRT-PCR and promoter reporter experiments, authors showed that Wnt4 acted as an inhibitor of Mstn expression. Moreover, study with $\mathrm{LiCl}$, strongly suggests that Wnt4 regulates negatively Mstn expression through activation of the canonical $\beta$-catenin pathway. However, while Wnt4 down-regulates Mstn expression in proliferative and differentiated cells, the activation of canonical signaling by $\mathrm{LiCl}$ inhibits Mstn expression only when cells are in proliferative or early differentiated states. Thus, in function of the differentiation state, various signaling pathways can be implicated in the inhibition of Mstn expression by Wnt4 in myogenic cells. A biphasic mode of action of Wnt4 can be proposed: in proliferative and early differentiated stages, Wnt 4 acts by inducing canonical signaling, and later in the differentiation, canonical pathways is relaxed and another pathway maintains Mstn at low level. However, the fact that Wnt4 displayed the strongest CAGA reporter inhibiting activity in proliferative myoblasts, whereas Wnt4 had 
the strongest Mstn expression inhibiting activity in differentiated myoblasts, implies that Wnt4 regulates both Mstn expression and Mstn/Smad signaling pathway. In silico analysis in the Mstn promoter revealed the presence of three putative Tcf/LEF binding sites within a $2-\mathrm{kb}$ sequence upstream of the Mstn gene at position $-1889,-1028$, and -743 confirming the observed regulation of the Mstn expression by $\mathrm{Wnt} / \beta$-catenin pathway. Analyze of reciprocal regulation of the both signaling pathways showed that whereas Mstn inhibits the accumulation of nuclear $\beta$-catenin in differentiated C2C12 [36], Mstn was not able to inhibit Tcf/LEF activity induced by Wnt4 overexpression in proliferative and differentiated C2C12 myoblasts [37]. Thus, contrary to adipogenic differentiation of human bone marrow-derived mesenchymal stem cells in which there is a cross-communication of the Mstn signal with Wnt/ $\beta$-catenin pathway, Wnt $4 / \beta$-catenin signaling pathway is not affected by Mstn.

Mstn has been described as an inhibitor of myotube formation in C2C12 and satellite cells $[32,33,34,35]$. The reversion of Wnt4 activity by recombinant Mstn and the absence of hypertrophic activity of this factor in Mstn-/- mice demonstrated clearly that Wnt4 requires the presence of Mstn to elicit its differentiation promoting activity [37]. Thus the negative regulation of Mstn by Wnt4 is a crucial step for the myotube formation and hypertrophy. The fact that the addition of Mstn reverses the hypertrophic activity of Wnt4 but does not reverse the Wnt4-induced CAGA reporter inhibition implies that 1) Wnt4 acts upstream of Mstn and that 2) Wnt4 inhibits CAGA reporter by another pathway than Mstn/Smad signaling. Furthermore, the demonstration that Wnt4 can dominantly overcome the expression and activity of atrophic Mstn opens possibilities of the manipulation of Wnt4 or $\beta$-catenin levels as a likely target for therapeutic design.

\section{Conclusion}

Development, growth and maintenance of muscle mass are critical for long-term health and quality of life. In this regard, activation of satellite cells and regulation of anabolic/catabolic muscular pathways play key roles. Production of new myofibrils and degradation of existing proteins is a delicate equilibrium, which, depending on the condition, can promote muscle growth or loss. In this matter, skeletal muscle has the capacity to continuously regulate its size in response to a variety of external cues and serves as the most significant repository for protein in the body of healthy adult humans ( $50 \%$ total protein content). To achieve a correct development and to maintain homeostasis, the biological response of the skeletal muscle implies a multitude of regulatory signaling pathways that orchestrates myogenesis in embryonic development and enables adult muscle repair. There is much interest in understanding the cellular and molecular mechanisms underlying skeletal muscle homeostasis and regeneration in different contexts because such knowledge might help in the development of cell therapies for diseases characterized by skeletal muscle degeneration. As described in this review, it is clear that Wnt play multiple and essential actions both in developmental and postnatal muscles. Depending not only of the Wnt signaling pathways implicated but also of the other interacting signaling pathways, Wnt proteins can act to promote or inhibit myogenesis. Further study will be necessary to elucidate the complex network that regulates embryonic and adult myogenesis. 


\section{Author details}

Yann Fedon, Anne Bonnieu, Barbara Vernus, Francis Bacou and Henri Bernardi* INRA, UMR866 Dynamique Musculaire Et Métabolisme, Montpellier, France

Stéphanie Gay

INRA, LPG Campus de Baulieu, Rennes France

\section{References}

[1] Kusserow A, Pang K, Sturm C, Hrouda M, Lentfer J, et al. (2005) Unexpected complexity of the Wnt gene family in a sea anemone. Nature 433: 156-160.

[2] Borello U, Berarducci B, Murphy P, Bajard L, Buffa V, et al. (2006) The Wnt/beta-catenin pathway regulates Gli-mediated Myf5 expression during somitogenesis. Development 133: 3723-3732.

[3] Moon RT, Bowerman B, Boutros M, Perrimon N (2002) The promise and perils of Wnt signaling through beta-catenin. Science 296: 1644-1646.

[4] Cadigan KM, Nusse R (1997) Wnt signaling: a common theme in animal development. Genes Dev 11: 3286-3305.

[5] Church VL, Francis-West P (2002) Wnt signalling during limb development. Int J Dev Biol 46: 927-936.

[6] Veeman MT, Axelrod JD, Moon RT (2003) A second canon. Functions and mechanisms of beta-catenin-independent Wnt signaling. Dev Cell 5: 367-377.

[7] Logan CY, Nusse R (2004) The Wnt signaling pathway in development and disease. Annu Rev Cell Dev Biol 20: 781-810.

[8] Abiola M, Favier M, Christodoulou-Vafeiadou E, Pichard AL, Martelly I, et al. (2009) Activation of Wnt/beta-catenin signaling increases insulin sensitivity through a reciprocal regulation of Wnt10b and SREBP-1c in skeletal muscle cells. PLoS One 4: e8509.

[9] Brisken C, Heineman A, Chavarria T, Elenbaas B, Tan J, et al. (2000) Essential function of Wnt-4 in mammary gland development downstream of progesterone signaling. Genes Dev 14: 650-654.

[10] Kim Y, Kobayashi A, Sekido R, DiNapoli L, Brennan J, et al. (2006) Fgf9 and Wnt4 act as antagonistic signals to regulate mammalian sex determination. PLoS Biol 4: e187.

[11] Nishizuka M, Koyanagi A, Osada S, Imagawa M (2008) Wnt4 and Wnt5a promote adipocyte differentiation. FEBS Lett 582: 3201-3205.

[12] Park JS, Valerius MT, McMahon AP (2007) Wnt/beta-catenin signaling regulates nephron induction during mouse kidney development. Development 134: 2533-2539.

[13] Bryja V, Schambony A, Cajanek L, Dominguez I, Arenas E, et al. (2008) Beta-arrestin and casein kinase 1/2 define distinct branches of non-canonical WNT signalling pathways. EMBO Rep 9: 1244-1250.

\footnotetext{
${ }^{*}$ Corresponding Author
} 
[14] Kohn AD, Moon RT (2005) Wnt and calcium signaling: beta-catenin-independent pathways. Cell Calcium 38: 439-446.

[15] Koyanagi M, Haendeler J, Badorff C, Brandes RP, Hoffmann J, et al. (2005) Noncanonical Wnt signaling enhances differentiation of human circulating progenitor cells to cardiomyogenic cells. J Biol Chem 280: 16838-16842.

[16] Minami Y, Oishi I, Endo M, Nishita M (2010) Ror-family receptor tyrosine kinases in noncanonical Wnt signaling: their implications in developmental morphogenesis and human diseases. Dev Dyn 239: 1-15.

[17] Tu X, Joeng KS, Nakayama KI, Nakayama K, Rajagopal J, et al. (2007) Noncanonical Wnt signaling through $\mathrm{G}$ protein-linked PKCdelta activation promotes bone formation. Dev Cell 12: 113-127.

[18] Neumann CJ, Cohen SM (1997) Long-range action of Wingless organizes the dorsalventral axis of the Drosophila wing. Development 124: 871-880.

[19] Strigini M, Cohen SM (2000) Wingless gradient formation in the Drosophila wing. Curr Biol 10: 293-300.

[20] Zecca M, Basler K, Struhl G (1996) Direct and long-range action of a wingless morphogen gradient. Cell 87: 833-844.

[21] Bischoff R (1975) Regeneration of single skeletal muscle fibers in vitro. Anat Rec 182: 215-235.

[22] Konigsberg UR, Lipton BH, Konigsberg IR (1975) The regenerative response of single mature muscle fibers isolated in vitro. Dev Biol 45: 260-275.

[23] Lipton BH, Schultz E (1979) Developmental fate of skeletal muscle satellite cells. Science 205: 1292-1294.

[24] Brack AS, Conboy MJ, Roy S, Lee M, Kuo CJ, et al. (2007) Increased Wnt signaling during aging alters muscle stem cell fate and increases fibrosis. Science 317: 807-810.

[25] Munsterberg AE, Kitajewski J, Bumcrot DA, McMahon AP, Lassar AB (1995) Combinatorial signaling by Sonic hedgehog and Wnt family members induces myogenic bHLH gene expression in the somite. Genes Dev 9: 2911-2922.

[26] Polesskaya A, Seale P, Rudnicki MA (2003) Wnt signaling induces the myogenic specification of resident CD45+ adult stem cells during muscle regeneration. Cell 113: 841-852.

[27] von Maltzahn J, Bentzinger CF, Rudnicki MA (2012) Wnt7a-Fzd7 signalling directly activates the Akt/mTOR anabolic growth pathway in skeletal muscle. Nat Cell Biol 14: 186-191.

[28] Steelman CA, Recknor JC, Nettleton D, Reecy JM (2006) Transcriptional profiling of myostatin-knockout mice implicates Wnt signaling in postnatal skeletal muscle growth and hypertrophy. Faseb J 20: 580-582.

[29] Kambadur R, Sharma M, Smith TP, Bass JJ (1997) Mutations in myostatin (GDF8) in double-muscled Belgian Blue and Piedmontese cattle. Genome Res 7: 910-916.

[30] McPherron AC, Lawler AM, Lee SJ (1997) Regulation of skeletal muscle mass in mice by a new TGF-beta superfamily member. Nature 387: 83-90. 
[31] Williams MS (2004) Myostatin mutation associated with gross muscle hypertrophy in a child. N Engl J Med 351: 1030-1031; author reply 1030-1031.

[32] Joulia D, Bernardi H, Garandel V, Rabenoelina F, Vernus B, et al. (2003) Mechanisms involved in the inhibition of myoblast proliferation and differentiation by myostatin. Exp Cell Res 286: 263-275.

[33] Langley B, Thomas M, Bishop A, Sharma M, Gilmour S, et al. (2002) Myostatin inhibits myoblast differentiation by down-regulating MyoD expression. J Biol Chem 277: 4983149840.

[34] Rios R, Carneiro I, Arce VM, Devesa J (2002) Myostatin is an inhibitor of myogenic differentiation. Am J Physiol Cell Physiol 282: C993-999.

[35] Trendelenburg AU, Meyer A, Rohner D, Boyle J, Hatakeyama S, et al. (2009) Myostatin reduces Akt/TORC1/p70S6K signaling, inhibiting myoblast differentiation and myotube size. Am J Physiol Cell Physiol 296: C1258-1270.

[36] Guo W, Flanagan J, Jasuja R, Kirkland J, Jiang L, et al. (2008) The effects of myostatin on adipogenic differentiation of human bone marrow-derived mesenchymal stem cells are mediated through cross-communication between Smad3 and Wnt/beta-catenin signaling pathways. J Biol Chem 283: 9136-9145.

[37] Bernardi H, Gay S, Fedon Y, Vernus B, Bonnieu A, et al. (2011) Wnt4 activates the canonical beta-catenin pathway and regulates negatively myostatin: functional implication in myogenesis. Am J Physiol Cell Physiol 300: C1122-1138.

[38] Wodarz A, Nusse R (1998) Mechanisms of Wnt signaling in development. Annu Rev Cell Dev Biol 14: 59-88.

[39] Fradkin LG, Noordermeer JN, Nusse R (1995) The Drosophila Wnt protein DWnt-3 is a secreted glycoprotein localized on the axon tracts of the embryonic CNS. Dev Biol 168: 202-213.

[40] Miller JR (2002) The Wnts. Genome Biol 3: REVIEWS3001.

[41] Willert K, Brown JD, Danenberg E, Duncan AW, Weissman IL, et al. (2003) Wnt proteins are lipid-modified and can act as stem cell growth factors. Nature 423: 448-452.

[42] Mason JO, Kitajewski J, Varmus HE (1992) Mutational analysis of mouse Wnt-1 identifies two temperature-sensitive alleles and attributes of Wnt-1 protein essential for transformation of a mammary cell line. Mol Biol Cell 3: 521-533.

[43] Zakin LD, Mazan S, Maury M, Martin N, Guenet JL, et al. (1998) Structure and expression of Wnt13, a novel mouse Wnt2 related gene. Mech Dev 73: 107-116.

[44] Binari RC, Staveley BE, Johnson WA, Godavarti R, Sasisekharan R, et al. (1997) Genetic evidence that heparin-like glycosaminoglycans are involved in wingless signaling. Development 124: 2623-2632.

[45] Reichsman F, Smith L, Cumberledge S (1996) Glycosaminoglycans can modulate extracellular localization of the wingless protein and promote signal transduction. J Cell Biol 135: 819-827.

[46] Hausmann G, Banziger C, Basler K (2007) Helping Wingless take flight: how WNT proteins are secreted. Nat Rev Mol Cell Biol 8: 331-336. 
[47] Neumann S, Coudreuse DY, van der Westhuyzen DR, Eckhardt ER, Korswagen HC, et al. (2009) Mammalian Wnt3a is released on lipoprotein particles. Traffic 10: 334-343.

[48] Panakova D, Sprong H, Marois E, Thiele C, Eaton S (2005) Lipoprotein particles are required for Hedgehog and Wingless signalling. Nature 435: 58-65.

[49] Schulte G, Bryja V, Rawal N, Castelo-Branco G, Sousa KM, et al. (2005) Purified Wnt-5a increases differentiation of midbrain dopaminergic cells and dishevelled phosphorylation. J Neurochem 92: 1550-1553.

[50] Yang-Snyder J, Miller JR, Brown JD, Lai CJ, Moon RT (1996) A frizzled homolog functions in a vertebrate Wnt signaling pathway. Curr Biol 6: 1302-1306.

[51] Huang HC, Klein PS (2004) The Frizzled family: receptors for multiple signal transduction pathways. Genome Biol 5: 234.

[52] Mikels AJ, Nusse R (2006) Wnts as ligands: processing, secretion and reception. Oncogene 25: 7461-7468.

[53] Wong GT, Gavin BJ, McMahon AP (1994) Differential transformation of mammary epithelial cells by Wnt genes. Mol Cell Biol 14: 6278-6286.

[54] Shimizu H, Julius MA, Giarre M, Zheng Z, Brown AM, et al. (1997) Transformation by Wnt family proteins correlates with regulation of beta-catenin. Cell Growth Differ 8: 1349-1358.

[55] Bernard P, Fleming A, Lacombe A, Harley VR, Vilain E (2008) Wnt4 inhibits betacatenin/TCF signalling by redirecting beta-catenin to the cell membrane. Biol Cell 100: 167-177.

[56] Jordan BK, Shen JH, Olaso R, Ingraham HA, Vilain E (2003) Wnt4 overexpression disrupts normal testicular vasculature and inhibits testosterone synthesis by repressing steroidogenic factor 1/beta-catenin synergy. Proc Natl Acad Sci U S A 100: 10866-10871.

[57] Liu CF, Parker K, Yao HH (2010) WNT4/beta-catenin pathway maintains female germ cell survival by inhibiting activin betaB in the mouse fetal ovary. PLoS One 5: e10382.

[58] Lyons JP, Mueller UW, Ji H, Everett C, Fang X, et al. (2004) Wnt-4 activates the canonical beta-catenin-mediated Wnt pathway and binds Frizzled-6 CRD: functional implications of Wnt/beta-catenin activity in kidney epithelial cells. Exp Cell Res 298: 369-387.

[59] Surendran K, McCaul SP, Simon TC (2002) A role for Wnt-4 in renal fibrosis. Am J Physiol Renal Physiol 282: F431-441.

[60] Takata H, Terada K, Oka H, Sunada Y, Moriguchi T, et al. (2007) Involvement of Wnt4 signaling during myogenic proliferation and differentiation of skeletal muscle. Dev Dyn 236: $2800-2807$.

[61] Terada Y, Tanaka H, Okado T, Shimamura H, Inoshita S, et al. (2003) Expression and function of the developmental gene Wnt-4 during experimental acute renal failure in rats. J Am Soc Nephrol 14: 1223-1233.

[62] Le Grand F, Jones AE, Seale V, Scime A, Rudnicki MA (2009) Wnt7a activates the planar cell polarity pathway to drive the symmetric expansion of satellite stem cells. Cell Stem Cell 4: 535-547. 
[63] Kengaku M, Capdevila J, Rodriguez-Esteban C, De La Pena J, Johnson RL, et al. (1998) Distinct WNT pathways regulating AER formation and dorsoventral polarity in the chick limb bud. Science 280: 1274-1277.

[64] Strutt DI, Weber U, Mlodzik M (1997) The role of RhoA in tissue polarity and Frizzled signalling. Nature 387: 292-295.

[65] Boutros M, Mlodzik M (1999) Dishevelled: at the crossroads of divergent intracellular signaling pathways. Mech Dev 83: 27-37.

[66] Habas R, Kato Y, He X (2001) Wnt/Frizzled activation of Rho regulates vertebrate gastrulation and requires a novel Formin homology protein Daam1. Cell 107: 843-854.

[67] Winter CG, Wang B, Ballew A, Royou A, Karess R, et al. (2001) Drosophila Rhoassociated kinase (Drok) links Frizzled-mediated planar cell polarity signaling to the actin cytoskeleton. Cell 105: 81-91.

[68] Fanto M, McNeill H (2004) Planar polarity from flies to vertebrates. J Cell Sci 117: 527533.

[69] Bhanot P, Brink M, Samos CH, Hsieh JC, Wang Y, et al. (1996) A new member of the frizzled family from Drosophila functions as a Wingless receptor. Nature 382: 225-230.

[70] Bhat KM (1998) frizzled and frizzled 2 play a partially redundant role in wingless signaling and have similar requirements to wingless in neurogenesis. Cell 95: 1027-1036.

[71] Hsieh JC, Rattner A, Smallwood PM, Nathans J (1999) Biochemical characterization of Wnt-frizzled interactions using a soluble, biologically active vertebrate Wnt protein. Proc Natl Acad Sci U S A 96: 3546-3551.

[72] Chen CM, Strapps W, Tomlinson A, Struhl G (2004) Evidence that the cysteine-rich domain of Drosophila Frizzled family receptors is dispensable for transducing Wingless. Proc Natl Acad Sci U S A 101: 15961-15966.

[73] Zhang J, Carthew RW (1998) Interactions between Wingless and DFz2 during Drosophila wing development. Development 125: 3075-3085.

[74] Dann CE, Hsieh JC, Rattner A, Sharma D, Nathans J, et al. (2001) Insights into Wnt binding and signalling from the structures of two Frizzled cysteine-rich domains. Nature 412: 86-90.

[75] Hsieh JC (2004) Specificity of WNT-receptor interactions. Front Biosci 9: 1333-1338.

[76] Rulifson EJ, Wu CH, Nusse R (2000) Pathway specificity by the bifunctional receptor frizzled is determined by affinity for wingless. Mol Cell 6: 117-126.

[77] Nusse R, Rulifson E, Fish M, Harryman-Samos C, Brink M, et al. (2000) Interactions between wingless and frizzled molecules in Drosophila. Ernst Schering Res Found Workshop: 1-11.

[78] Cadigan KM, Liu YI (2006) Wnt signaling: complexity at the surface. J Cell Sci 119: 395402.

[79] He X, Semenov M, Tamai K, Zeng X (2004) LDL receptor-related proteins 5 and 6 in Wnt/beta-catenin signaling: arrows point the way. Development 131: 1663-1677.

[80] Tamai K, Semenov M, Kato Y, Spokony R, Liu C, et al. (2000) LDL-receptor-related proteins in Wnt signal transduction. Nature 407: 530-535. 
[81] Kato M, Patel MS, Levasseur R, Lobov I, Chang BH, et al. (2002) Cbfa1-independent decrease in osteoblast proliferation, osteopenia, and persistent embryonic eye vascularization in mice deficient in Lrp5, a Wnt coreceptor. J Cell Biol 157: 303-314.

[82] Liu G, Bafico A, Harris VK, Aaronson SA (2003) A novel mechanism for Wnt activation of canonical signaling through the LRP6 receptor. Mol Cell Biol 23: 5825-5835.

[83] Cong F, Schweizer L, Varmus H (2004) Wnt signals across the plasma membrane to activate the beta-catenin pathway by forming oligomers containing its receptors, Frizzled and LRP. Development 131: 5103-5115.

[84] Pinson KI, Brennan J, Monkley S, Avery BJ, Skarnes WC (2000) An LDL-receptor-related protein mediates Wnt signalling in mice. Nature 407: 535-538.

[85] Wehrli M, Dougan ST, Caldwell K, O'Keefe L, Schwartz S, et al. (2000) arrow encodes an LDL-receptor-related protein essential for Wingless signalling. Nature 407: 527-530.

[86] Jones SE, Jomary C (2002) Secreted Frizzled-related proteins: searching for relationships and patterns. Bioessays 24: 811-820.

[87] Glinka A, Wu W, Delius H, Monaghan AP, Blumenstock C, et al. (1998) Dickkopf-1 is a member of a new family of secreted proteins and functions in head induction. Nature 391: 357-362.

[88] Krupnik VE, Sharp JD, Jiang C, Robison K, Chickering TW, et al. (1999) Functional and structural diversity of the human Dickkopf gene family. Gene 238: 301-313.

[89] Kawano Y, Kypta R (2003) Secreted antagonists of the Wnt signalling pathway. J Cell Sci 116: 2627-2634.

[90] Rattner A, Hsieh JC, Smallwood PM, Gilbert DJ, Copeland NG, et al. (1997) A family of secreted proteins contains homology to the cysteine-rich ligand-binding domain of frizzled receptors. Proc Natl Acad Sci U S A 94: 2859-2863.

[91] Melkonyan HS, Chang WC, Shapiro JP, Mahadevappa M, Fitzpatrick PA, et al. (1997) SARPs: a family of secreted apoptosis-related proteins. Proc Natl Acad Sci U S A 94: 13636-13641.

[92] Uren A, Reichsman F, Anest V, Taylor WG, Muraiso K, et al. (2000) Secreted frizzledrelated protein-1 binds directly to Wingless and is a biphasic modulator of Wnt signaling. J Biol Chem 275: 4374-4382.

[93] Lin K, Wang S, Julius MA, Kitajewski J, Moos M, Jr., et al. (1997) The cysteine-rich frizzled domain of Frzb-1 is required and sufficient for modulation of Wnt signaling. Proc Natl Acad Sci U S A 94: 11196-11200.

[94] Banyai L, Patthy L (1999) The NTR module: domains of netrins, secreted frizzled related proteins, and type I procollagen C-proteinase enhancer protein are homologous with tissue inhibitors of metalloproteases. Protein Sci 8: 1636-1642.

[95] Bafico A, Liu G, Yaniv A, Gazit A, Aaronson SA (2001) Novel mechanism of Wnt signalling inhibition mediated by Dickkopf-1 interaction with LRP6/Arrow. Nat Cell Biol 3: 683-686.

[96] Wharton KA, Jr. (2003) Runnin' with the Dvl: proteins that associate with Dsh/Dvl and their significance to Wnt signal transduction. Dev Biol 253: 1-17. 
[97] Miller JR, Hocking AM, Brown JD, Moon RT (1999) Mechanism and function of signal transduction by the Wnt/beta-catenin and Wnt/Ca2+ pathways. Oncogene 18: 78607872 .

[98] Wallingford JB, Fraser SE, Harland RM (2002) Convergent extension: the molecular control of polarized cell movement during embryonic development. Dev Cell 2: 695706.

[99] Marlow F, Topczewski J, Sepich D, Solnica-Krezel L (2002) Zebrafish Rho kinase 2 acts downstream of Wnt11 to mediate cell polarity and effective convergence and extension movements. Curr Biol 12: 876-884.

[100] Franco CA, Liebner S, Gerhardt H (2009) Vascular morphogenesis: a Wnt for every vessel? Curr Opin Genet Dev 19: 476-483.

[101] Miller JR, Moon RT (1996) Signal transduction through beta-catenin and specification of cell fate during embryogenesis. Genes Dev 10: 2527-2539.

[102] Willert K, Nusse R (1998) Beta-catenin: a key mediator of Wnt signaling. Curr Opin Genet Dev 8: 95-102.

[103] Rubinfeld B, Albert I, Porfiri E, Fiol C, Munemitsu S, et al. (1996) Binding of GSK3beta to the APC-beta-catenin complex and regulation of complex assembly. Science 272: 1023-1026.

[104] Rubinfeld B, Souza B, Albert I, Muller O, Chamberlain SH, et al. (1993) Association of the APC gene product with beta-catenin. Science 262: 1731-1734.

[105] Su LK, Vogelstein B, Kinzler KW (1993) Association of the APC tumor suppressor protein with catenins. Science 262: 1734-1737.

[106] Yost C, Farr GH, 3rd, Pierce SB, Ferkey DM, Chen MM, et al. (1998) GBP, an inhibitor of GSK-3, is implicated in Xenopus development and oncogenesis. Cell 93: 1031-1041.

[107] Zeng L, Fagotto F, Zhang T, Hsu W, Vasicek TJ, et al. (1997) The mouse Fused locus encodes Axin, an inhibitor of the Wnt signaling pathway that regulates embryonic axis formation. Cell 90: 181-192.

[108] Yost C, Torres M, Miller JR, Huang E, Kimelman D, et al. (1996) The axis-inducing activity, stability, and subcellular distribution of beta-catenin is regulated in Xenopus embryos by glycogen synthase kinase 3. Genes Dev 10: 1443-1454.

[109] Aberle H, Bauer A, Stappert J, Kispert A, Kemler R (1997) beta-catenin is a target for the ubiquitin-proteasome pathway. EMBO J 16: 3797-3804.

[110] Morin PJ, Sparks AB, Korinek V, Barker N, Clevers H, et al. (1997) Activation of betacatenin-Tcf signaling in colon cancer by mutations in beta-catenin or APC. Science 275 : 1787-1790.

[111] Rubinfeld B, Robbins P, El-Gamil M, Albert I, Porfiri E, et al. (1997) Stabilization of beta-catenin by genetic defects in melanoma cell lines. Science 275: 1790-1792.

[112] Itoh K, Brott BK, Bae GU, Ratcliffe MJ, Sokol SY (2005) Nuclear localization is required for Dishevelled function in Wnt/beta-catenin signaling. J Biol 4: 3.

[113] Behrens J, von Kries JP, Kuhl M, Bruhn L, Wedlich D, et al. (1996) Functional interaction of beta-catenin with the transcription factor LEF-1. Nature 382: 638-642. 
[114] Molenaar M, van de Wetering M, Oosterwegel M, Peterson-Maduro J, Godsave S, et al. (1996) XTcf-3 transcription factor mediates beta-catenin-induced axis formation in Xenopus embryos. Cell 86: 391-399.

[115] van de Wetering M, Cavallo R, Dooijes D, van Beest M, van Es J, et al. (1997) Armadillo coactivates transcription driven by the product of the Drosophila segment polarity gene dTCF. Cell 88: 789-799.

[116] Brannon M, Brown JD, Bates R, Kimelman D, Moon RT (1999) XCtBP is a XTcf-3 corepressor with roles throughout Xenopus development. Development 126: 3159-3170.

[117] Nelson WJ, Nusse R (2004) Convergence of Wnt, beta-catenin, and cadherin pathways. Science 303: 1483-1487.

[118] Perez-Moreno M, Fuchs E (2006) Catenins: keeping cells from getting their signals crossed. Dev Cell 11: 601-612.

[119] Hecht A, Kemler R (2000) Curbing the nuclear activities of beta-catenin. Control over Wnt target gene expression. EMBO Rep 1: 24-28.

[120] Wang HY, Malbon CC (2003) Wnt signaling, Ca2+, and cyclic GMP: visualizing Frizzled functions. Science 300: 1529-1530.

[121] Kuhl M, Sheldahl LC, Park M, Miller JR, Moon RT (2000) The Wnt/Ca2+ pathway: a new vertebrate Wnt signaling pathway takes shape. Trends Genet 16: 279-283.

[122] Kuhl M, Sheldahl LC, Malbon CC, Moon RT (2000) Ca(2+)/calmodulin-dependent protein kinase II is stimulated by Wnt and Frizzled homologs and promotes ventral cell fates in Xenopus. J Biol Chem 275: 12701-12711.

[123] Slusarski DC, Corces VG, Moon RT (1997) Interaction of Wnt and a Frizzled homologue triggers G-protein-linked phosphatidylinositol signalling. Nature 390: 410413.

[124] Nusse R (1999) WNT targets. Repression and activation. Trends Genet 15: 1-3.

[125] Vladar EK, Antic D, Axelrod JD (2009) Planar cell polarity signaling: the developing cell's compass. Cold Spring Harb Perspect Biol 1: a002964.

[126] Strutt D, Warrington SJ (2008) Planar polarity genes in the Drosophila wing regulate the localisation of the FH3-domain protein Multiple Wing Hairs to control the site of hair production. Development 135: 3103-3111.

[127] Katoh M (2005) WNT/PCP signaling pathway and human cancer (review). Oncol Rep 14: 1583-1588.

[128] Buckingham M, Bajard L, Chang T, Daubas P, Hadchouel J, et al. (2003) The formation of skeletal muscle: from somite to limb. J Anat 202: 59-68.

[129] Parker MH, Seale P, Rudnicki MA (2003) Looking back to the embryo: defining transcriptional networks in adult myogenesis. Nat Rev Genet 4: 497-507.

[130] Gridley T (2006) The long and short of it: somite formation in mice. Dev Dyn 235: 2330-2336.

[131] Gilbert SF (2003) The morphogenesis of evolutionary developmental biology. Int J Dev Biol 47: 467-477. 
[132] Tajbakhsh S, Borello U, Vivarelli E, Kelly R, Papkoff J, et al. (1998) Differential activation of Myf5 and MyoD by different Wnts in explants of mouse paraxial mesoderm and the later activation of myogenesis in the absence of Myf5. Development 125: 4155-4162.

[133] Hollway G, Currie P (2005) Vertebrate myotome development. Birth Defects Res C Embryo Today 75: 172-179.

[134] Brent AE, Tabin CJ (2002) Developmental regulation of somite derivatives: muscle, cartilage and tendon. Curr Opin Genet Dev 12: 548-557.

[135] Ordahl CP, Le Douarin NM (1992) Two myogenic lineages within the developing somite. Development 114: 339-353.

[136] Kassar-Duchossoy L, Giacone E, Gayraud-Morel B, Jory A, Gomes D, et al. (2005) Pax3/Pax7 mark a novel population of primitive myogenic cells during development. Genes Dev 19: 1426-1431.

[137] Braun T, Rudnicki MA, Arnold HH, Jaenisch R (1992) Targeted inactivation of the muscle regulatory gene Myf- 5 results in abnormal rib development and perinatal death. Cell 71: 369-382.

[138] Tajbakhsh S, Rocancourt D, Buckingham M (1996) Muscle progenitor cells failing to respond to positional cues adopt non-myogenic fates in myf-5 null mice. Nature 384: 266-270.

[139] Lagha M, Sato T, Bajard L, Daubas P, Esner M, et al. (2008) Regulation of skeletal muscle stem cell behavior by Pax3 and Pax7. Cold Spring Harb Symp Quant Biol 73: 307-315.

[140] Francis-West PH, Antoni L, Anakwe K (2003) Regulation of myogenic differentiation in the developing limb bud. J Anat 202: 69-81.

[141] Buckingham M (2006) Myogenic progenitor cells and skeletal myogenesis in vertebrates. Curr Opin Genet Dev 16: 525-532.

[142] Tajbakhsh S, Rocancourt D, Cossu G, Buckingham M (1997) Redefining the genetic hierarchies controlling skeletal myogenesis: Pax-3 and Myf-5 act upstream of MyoD. Cell 89: 127-138.

[143] Relaix F, Rocancourt D, Mansouri A, Buckingham M (2005) A Pax3/Pax7-dependent population of skeletal muscle progenitor cells. Nature 435: 948-953.

[144] Buckingham M (2007) Skeletal muscle progenitor cells and the role of Pax genes. C R Biol 330: 530-533.

[145] Gros J, Manceau M, Thome V, Marcelle C (2005) A common somitic origin for embryonic muscle progenitors and satellite cells. Nature 435: 954-958.

[146] Schultz E (1996) Satellite cell proliferative compartments in growing skeletal muscles. Dev Biol 175: 84-94.

[147] Ben-Yair R, Kalcheim C (2008) Notch and bone morphogenetic protein differentially act on dermomyotome cells to generate endothelium, smooth, and striated muscle. J Cell Biol 180: 607-618. 
[148] Vasyutina E, Lenhard DC, Birchmeier C (2007) Notch function in myogenesis. Cell Cycle 6: 1451-1454.

[149] Cossu G, Borello U (1999) Wnt signaling and the activation of myogenesis in mammals. Embo J 18: 6867-6872.

[150] Teillet M, Watanabe Y, Jeffs P, Duprez D, Lapointe F, et al. (1998) Sonic hedgehog is required for survival of both myogenic and chondrogenic somitic lineages. Development 125: 2019-2030.

[151] Bentzinger CF, Wang YX, Rudnicki MA (2012) Building muscle: molecular regulation of myogenesis. Cold Spring Harb Perspect Biol 4.

[152] Duprez D, Fournier-Thibault C, Le Douarin N (1998) Sonic Hedgehog induces proliferation of committed skeletal muscle cells in the chick limb. Development 125: 495-505.

[153] Christ B, Brand-Saberi B (2002) Limb muscle development. Int J Dev Biol 46: 905-914.

[154] Munsterberg AE, Lassar AB (1995) Combinatorial signals from the neural tube, floor plate and notochord induce myogenic bHLH gene expression in the somite. Development 121: 651-660.

[155] Wagner J, Schmidt C, Nikowits W, Jr., Christ B (2000) Compartmentalization of the somite and myogenesis in chick embryos are influenced by wnt expression. Dev Biol 228: 86-94.

[156] Cossu G, Kelly R, Tajbakhsh S, Di Donna S, Vivarelli E, et al. (1996) Activation of different myogenic pathways: myf-5 is induced by the neural tube and MyoD by the dorsal ectoderm in mouse paraxial mesoderm. Development 122: 429-437.

[157] Borello U, Coletta M, Tajbakhsh S, Leyns L, De Robertis EM, et al. (1999) Transplacental delivery of the Wnt antagonist Frzb1 inhibits development of caudal paraxial mesoderm and skeletal myogenesis in mouse embryos. Development 126: 4247-4255.

[158] Gustafsson MK, Pan H, Pinney DF, Liu Y, Lewandowski A, et al. (2002) Myf5 is a direct target of long-range Shh signaling and Gli regulation for muscle specification. Genes Dev 16: 114-126.

[159] Alvarez-Medina R, Cayuso J, Okubo T, Takada S, Marti E (2008) Wnt canonical pathway restricts graded Shh/Gli patterning activity through the regulation of Gli3 expression. Development 135: 237-247.

[160] Gros J, Serralbo O, Marcelle C (2009) WNT11 acts as a directional cue to organize the elongation of early muscle fibres. Nature 457: 589-593.

[161] Baksh D, Boland GM, Tuan RS (2007) Cross-talk between Wnt signaling pathways in human mesenchymal stem cells leads to functional antagonism during osteogenic differentiation. J Cell Biochem 101: 1109-1124.

[162] Baksh D, Tuan RS (2007) Canonical and non-canonical Wnts differentially affect the development potential of primary isolate of human bone marrow mesenchymal stem cells. J Cell Physiol 212: 817-826. 
[163] Thomas M, Langley B, Berry C, Sharma M, Kirk S, et al. (2000) Myostatin, a negative regulator of muscle growth, functions by inhibiting myoblast proliferation. J Biol Chem 275: 40235-40243.

[164] Taylor WE, Bhasin S, Artaza J, Byhower F, Azam M, et al. (2001) Myostatin inhibits cell proliferation and protein synthesis in $\mathrm{C} 2 \mathrm{C} 12$ muscle cells. Am J Physiol Endocrinol Metab 280: E221-228.

[165] Manceau M, Gros J, Savage K, Thome V, McPherron A, et al. (2008) Myostatin promotes the terminal differentiation of embryonic muscle progenitors. Genes Dev 22: 668-681.

[166] Kollias HD, McDermott JC (2008) Transforming growth factor-beta and myostatin signaling in skeletal muscle. J Appl Physiol 104: 579-587.

[167] Grobet L, Martin LJ, Poncelet D, Pirottin D, Brouwers B, et al. (1997) A deletion in the bovine myostatin gene causes the double-muscled phenotype in cattle. Nat Genet 17: 71-74.

[168] McPherron AC, Lee SJ (1997) Double muscling in cattle due to mutations in the myostatin gene. Proc Natl Acad Sci U S A 94: 12457-12461.

[169] Schuelke M, Wagner KR, Stolz LE, Hubner C, Riebel T, et al. (2004) Myostatin mutation associated with gross muscle hypertrophy in a child. N Engl J Med 350: 26822688.

[170] Duprez D, Bell EJ, Richardson MK, Archer CW, Wolpert L, et al. (1996) Overexpression of BMP-2 and BMP-4 alters the size and shape of developing skeletal elements in the chick limb. Mech Dev 57: 145-157.

[171] Sela-Donenfeld D, Kalcheim C (2002) Localized BMP4-noggin interactions generate the dynamic patterning of noggin expression in somites. Dev Biol 246: 311-328.

[172] Amthor H, Christ B, Rashid-Doubell F, Kemp CF, Lang E, et al. (2002) Follistatin regulates bone morphogenetic protein-7 (BMP-7) activity to stimulate embryonic muscle growth. Dev Biol 243: 115-127.

[173] Souza TA, Chen X, Guo Y, Sava P, Zhang J, et al. (2008) Proteomic identification and functional validation of activins and bone morphogenetic protein 11 as candidate novel muscle mass regulators. Mol Endocrinol 22: 2689-2702.

[174] McCarthy JJ (2008) MicroRNA-206: the skeletal muscle-specific myomiR. Biochim Biophys Acta 1779: 682-691.

[175] Chen JF, Mandel EM, Thomson JM, Wu Q, Callis TE, et al. (2006) The role of microRNA-1 and microRNA-133 in skeletal muscle proliferation and differentiation. Nat Genet 38: 228-233.

[176] Sweetman D, Goljanek K, Rathjen T, Oustanina S, Braun T, et al. (2008) Specific requirements of MRFs for the expression of muscle specific microRNAs, miR-1, miR-206 and miR-133. Dev Biol 321: 491-499.

[177] Tedesco FS, Dellavalle A, Diaz-Manera J, Messina G, Cossu G (2010) Repairing skeletal muscle: regenerative potential of skeletal muscle stem cells. J Clin Invest 120: 11-19. 
[178] Cornelison DD, Wold BJ (1997) Single-cell analysis of regulatory gene expression in quiescent and activated mouse skeletal muscle satellite cells. Dev Biol 191: 270-283.

[179] Grounds MD, Garrett KL, Lai MC, Wright WE, Beilharz MW (1992) Identification of skeletal muscle precursor cells in vivo by use of MyoD1 and myogenin probes. Cell Tissue Res 267: 99-104.

[180] Zammit PS (2008) All muscle satellite cells are equal, but are some more equal than others? J Cell Sci 121: 2975-2982.

[181] Charge SB, Rudnicki MA (2004) Cellular and molecular regulation of muscle regeneration. Physiol Rev 84: 209-238.

[182] Dhawan J, Rando TA (2005) Stem cells in postnatal myogenesis: molecular mechanisms of satellite cell quiescence, activation and replenishment. Trends Cell Biol 15: 666-673.

[183] Price FD, Kuroda K, Rudnicki MA (2007) Stem cell based therapies to treat muscular dystrophy. Biochim Biophys Acta 1772: 272-283.

[184] Fukada S, Uezumi A, Ikemoto M, Masuda S, Segawa M, et al. (2007) Molecular signature of quiescent satellite cells in adult skeletal muscle. Stem Cells 25: 2448-2459.

[185] Kuang S, Rudnicki MA (2008) The emerging biology of satellite cells and their therapeutic potential. Trends Mol Med 14: 82-91.

[186] Sambasivan R, Tajbakhsh S (2007) Skeletal muscle stem cell birth and properties. Semin Cell Dev Biol 18: 870-882.

[187] Brack A (2009) Adult muscle stem cells avoid death and Paxes. Cell Stem Cell 5: 132134.

[188] Tajbakhsh S, Bober E, Babinet C, Pournin S, Arnold H, et al. (1996) Gene targeting the myf-5 locus with nlac $Z$ reveals expression of this myogenic factor in mature skeletal muscle fibres as well as early embryonic muscle. Dev Dyn 206: 291-300.

[189] Zammit PS, Golding JP, Nagata Y, Hudon V, Partridge TA, et al. (2004) Muscle satellite cells adopt divergent fates: a mechanism for self-renewal? J Cell Biol 166: 347357.

[190] Kuang S, Kuroda K, Le Grand F, Rudnicki MA (2007) Asymmetric self-renewal and commitment of satellite stem cells in muscle. Cell 129: 999-1010.

[191] Kassar-Duchossoy L, Gayraud-Morel B, Gomes D, Rocancourt D, Buckingham M, et al. (2004) Mrf4 determines skeletal muscle identity in Myf5:Myod double-mutant mice. Nature 431: 466-471.

[192] Shinin V, Gayraud-Morel B, Gomes D, Tajbakhsh S (2006) Asymmetric division and cosegregation of template DNA strands in adult muscle satellite cells. Nat Cell Biol 8: 677-687.

[193] Marcell TJ (2003) Sarcopenia: causes, consequences, and preventions. J Gerontol A Biol Sci Med Sci 58: M911-916.

[194] Conboy IM, Conboy MJ, Smythe GM, Rando TA (2003) Notch-mediated restoration of regenerative potential to aged muscle. Science 302: 1575-1577. 
[195] Goldspink G, Fernandes K, Williams PE, Wells DJ (1994) Age-related changes in collagen gene expression in the muscles of $\mathrm{mdx}$ dystrophic and normal mice. Neuromuscul Disord 4: 183-191.

[196] Conboy IM, Rando TA (2005) Aging, stem cells and tissue regeneration: lessons from muscle. Cell Cycle 4: 407-410.

[197] Conboy IM, Conboy MJ, Wagers AJ, Girma ER, Weissman IL, et al. (2005) Rejuvenation of aged progenitor cells by exposure to a young systemic environment. Nature 433: 760-764.

[198] Liu H, Fergusson MM, Castilho RM, Liu J, Cao L, et al. (2007) Augmented Wnt signaling in a mammalian model of accelerated aging. Science 317: 803-806.

[199] Dellavalle A, Sampaolesi M, Tonlorenzi R, Tagliafico E, Sacchetti B, et al. (2007) Pericytes of human skeletal muscle are myogenic precursors distinct from satellite cells. Nat Cell Biol 9: 255-267.

[200] Sampaolesi M, Blot S, D'Antona G, Granger N, Tonlorenzi R, et al. (2006) Mesoangioblast stem cells ameliorate muscle function in dystrophic dogs. Nature 444: 574-579.

[201] Galvez BG, Sampaolesi M, Brunelli S, Covarello D, Gavina M, et al. (2006) Complete repair of dystrophic skeletal muscle by mesoangioblasts with enhanced migration ability. J Cell Biol 174: 231-243.

[202] Sampaolesi M, Torrente Y, Innocenzi A, Tonlorenzi R, D'Antona G, et al. (2003) Cell therapy of alpha-sarcoglycan null dystrophic mice through intra-arterial delivery of mesoangioblasts. Science 301: 487-492.

[203] Mitchell KJ, Pannerec A, Cadot B, Parlakian A, Besson V, et al. (2010) Identification and characterization of a non-satellite cell muscle resident progenitor during postnatal development. Nat Cell Biol 12: 257-266.

[204] Gussoni E, Soneoka Y, Strickland CD, Buzney EA, Khan MK, et al. (1999) Dystrophin expression in the mdx mouse restored by stem cell transplantation. Nature 401: 390-394.

[205] LaBarge MA, Blau HM (2002) Biological progression from adult bone marrow to mononucleate muscle stem cell to multinucleate muscle fiber in response to injury. Cell 111: 589-601.

[206] Tanaka S, Terada K, Nohno T (2011) Canonical Wnt signaling is involved in switching from cell proliferation to myogenic differentiation of mouse myoblast cells. J Mol Signal 6: 12 .

[207] Otto A, Schmidt C, Luke G, Allen S, Valasek P, et al. (2008) Canonical Wnt signalling induces satellite-cell proliferation during adult skeletal muscle regeneration. J Cell Sci 121: 2939-2950.

[208] Lathrop B, Olson E, Glaser L (1985) Control by fibroblast growth factor of differentiation in the BC3H1 muscle cell line. J Cell Biol 100: 1540-1547.

[209] Anakwe K, Robson L, Hadley J, Buxton P, Church V, et al. (2003) Wnt signalling regulates myogenic differentiation in the developing avian wing. Development 130: 3503-3514. 
[210] Armstrong DD, Wong VL, Esser KA (2006) Expression of beta-catenin is necessary for physiological growth of adult skeletal muscle. Am J Physiol Cell Physiol 291: C185-188.

[211] Han XH, Jin YR, Seto M, Yoon JK (2011) A WNT/beta-catenin signaling activator, Rspondin, plays positive regulatory roles during skeletal myogenesis. J Biol Chem 286: 10649-10659.

[212] Bogdanovich S, Krag TO, Barton ER, Morris LD, Whittemore LA, et al. (2002) Functional improvement of dystrophic muscle by myostatin blockade. Nature 420: 418421.

[213] Rebbapragada A, Benchabane H, Wrana JL, Celeste AJ, Attisano L (2003) Myostatin signals through a transforming growth factor beta-like signaling pathway to block adipogenesis. Mol Cell Biol 23: 7230-7242.

[214] Derynck R, Zhang Y, Feng XH (1998) Smads: transcriptional activators of TGF-beta responses. Cell 95: 737-740.

[215] Massague J, Wotton D (2000) Transcriptional control by the TGF-beta/Smad signaling system. Embo J 19: 1745-1754. 